\title{
A RELIABLE METHOD FOR THE DETERMINATION OF URINARY ESTRIOL IN PREGNANCY
}

\section{U. GOEBELSMANN}

Department of Obstetrics and Gynecology, University of Michigan Medical School, Ann Arbor, Mich. (U.S.A.)

(Received October 2I, 1968)

\section{SUMMARY}

A reliable method for the estimation of urinary estriol in pregnancy is presented. This method is based upon acid hydrolysis, solvent partition, methylation and chromatography. Estriol is measured by colorimetry using the Kober reaction. All results are corrected for procedural loss by adding tritium-labelled estriol-I6-glucosiduronate to the unhydrolyzed urine.

This method proves to be sufficiently specific, accurate and precise. One operator may complete six assays within one working day.

It is emphasized that a comprehensive recovery control which includes the initial hydrolytic procedure is essential if estriol determinations are to serve as a diagnostic aid in obstetrics.

\section{INTRODUCTION}

Estriol excreted in the urine of pregnant women serves as a valuable indicator of fetal well-being. The bulk of the maternal urinary estriol is produced by the fetoplacental unit ${ }^{1}$. Estriol is readily transferred from the fetal compartment to the maternal circulation ${ }^{2-4}$. Maternal estriol metabolism is characterized by extensive conjugation, alteration of the estriol moiety to a limited extent, and a rapid urinary excretion, mainly in the form of estriol glucosiduronates ${ }^{5-7}$.

Fetal distress and/or placental insufficiency lead to prompt decrease in estriol production and excretion. Estriol determinations have therefore been considered helpful in timing delivery in pregnancies complicated by diabetes mellitus, hypertension and toxemia as well as placental insufficiency in order to prevent unnecessary prematurity and to reduce the risk of perinatal mortality ${ }^{8}$.

A number of estriol assays has been published. Many such methods are convenient, but only few are as reliable as the clinical importance demands. This paper presents a method for the determination of urinary estriol in pregnancy which is accurate as well as convenient. 


\section{EXPERIMENTAL}

\section{Trivial names}

Estriol: estra-I,3,5(I0)-triene-3,I6 $\alpha, \mathrm{I} 7 \beta$-triol; estriol-3-glucosiduronate: $\mathrm{I} 6 \alpha$, $\mathbf{I} 7 \beta$-dihydroxy-estra-I,3,5(Io)triene-3-yl- $\beta$-D-glucopyransiduronate; estriol-I6-glucosiduronate: 3 ,I $7 \beta$-dihydroxy-estra-I,3,5 (Io)-triene-I6 $\alpha$-yl- $\beta$-D-glucopyranosiduronate; estriol-3-methyl ether: 3 -methoxy-estra-I,3,5(Io)-triene-I $6 \alpha$, I7 $\beta$-diol.

\section{Reagents}

The reagents used were of analytical grade unless otherwise stated. All solvents except diethyl ether were distilled prior to use. Aluminum oxide $\left(\mathrm{Al}_{2} \mathrm{O}_{3}\right.$ Woelm neutral, activity I) was purchased from Alupharm Chemicals, New Orleans, La., U.S.A.;

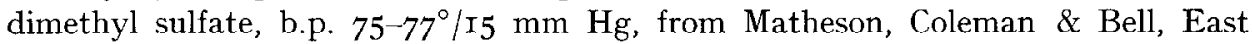
Rutherford, N.J., U.S.A.; $\left[6,7^{-3} \mathrm{H}\right]$ estriol from New England Nuclear Corporation, Boston, Mass., U.S.A.; hydroquinone, extra pure, and silica gel $G$ for thin-layer chromatography from E. Merck A.G., Darmstadt, Germany; and uridine-5'-diphosphoglucuronic acid from Sigma Chemical Company, St. Louis, Mo., U.S.A. Authentic estriol-I6-glucosiduronate was a gift from Professor W. Allen, St. Louis, Mo., U.S.A.

\section{Apparatus}

The radioactive material was measured in a Packard Model 3375 Liquid Scintillation Spectrometer. Colorimetry was performed on a Beckman DU spectrophotometer. Tubes for a counter-current distribution (CCD) apparatus were obtained from AB. Laboratorietjänst, Stockholm, Sweden, and assembled to a hand-operated CCD machine.

\section{Preparation of $\left[{ }^{3} \mathrm{H}\right]$ estriol-16-glucosiduronate}

$\left\lfloor 6,7{ }^{-3} \mathrm{H}\right]$ Estriol $\left(\mathrm{E}_{3}\right)$ was diluted to a specific activity (S. A.) of $5 \mu \mathrm{C}$ per $\mu \mathrm{g}$ and purified by paper partition chromatography. Its radiochemical homogeneity was tested by crystallizing one aliquot to constant S.A. Radiochemically pure $\left[{ }^{3} \mathrm{H}\right] \mathrm{E}_{\mathbf{3}}$ was incubated with an homogenate of human liver (autopsy material) and uridine- $5^{\prime}$ diphosphoglucuronic acid according to the method of Slaunwhite et al. ${ }^{9}$. The resulting $\left[{ }^{3} \mathrm{H}\right]$ estriol-I6-glucosiduronate $\left(\mathrm{E}_{3}-\mathrm{I} 6 \mathrm{Gl}\right)$ was extracted from the incubation mixture and purified by a 24 -transfer CCD in ethyl acetate $250, n$-butanol $250,0.2 \mathrm{~N} \mathrm{NH}_{4} \mathrm{OH}$ 500 , where $\mathrm{E}_{3}-\mathrm{I} 6 \mathrm{Gl}$ has a partition coefficient $(K)$ of approximately $\mathrm{I}$, and by gel filtration on Sephadex $\mathrm{G}-25^{10}$. The radiochemical homogeneity of the $\left.{ }^{[3} \mathrm{H}\right] \mathrm{E}_{3}-\mathrm{I} 6 \mathrm{Gl}$ fraction was assessed by subjecting one aliquot to a 24 -transfer CCD in ethyl acetate 500 , o.I $N$ hydrochloric acid following the admixture of authentic $\mathrm{E}_{3}-\mathrm{I} 6 \mathrm{Gl}$. No ${ }^{3} \mathrm{H}$ labelled material could be dissociated from the carrier which was assayed by the Kober reaction according to Nocke's modification ${ }^{11}$. Constant S.A. was obtained throughout the binomial distribution curve. Additional evidence that the conjugate prepared by this method is $\mathrm{E}_{3}-\mathrm{I} 6 \mathrm{Gl}$ has been presented elsewhere ${ }^{2}$.

\section{Hydrolysis and solvent partition}

Approximately 3000 counts/min of ${ }^{3} \mathrm{H}$-labelled $\mathrm{E}_{3}-\mathrm{I} 6 \mathrm{Gl}$ are added to $\mathrm{I} \%$ or $0.5 \%$ of a total 24 -hour urine collection from women less than 30 weeks and 30 or more weeks pregnant, respectively. Distilled water is added to increase the volume 
to $50 \mathrm{ml}$, to which Io $\mathrm{ml}$ of conc. hydrochloric acid is added. The specimens are boiled for $30 \mathrm{~min}$ under a reflux condenser. The hydrolyzate is cooled and extracted once with $\mathrm{I} 20 \mathrm{ml}$ of diethyl ether. The ether extract is washed twice with $25 \mathrm{ml}$ of a mixture of $\mathrm{I}_{5} \mathrm{O} \mathrm{ml}$ of $5 \mathrm{~N} \mathrm{NaOH}$ and rooo $\mathrm{ml} 8 \%$ (w/v) sodium bicarbonate and twice with Io $\mathrm{ml}$ of distilled water. The ether is evaporated and its residue is partitioned between $50 \mathrm{ml}$ of benzene-petroleum ether $(\mathrm{I}: \mathrm{I} / \mathrm{V}: \mathrm{V})$ and $50 \mathrm{ml}$ of water containing $2 \%$ ethanol $(v: v)$.

\section{Methylation and chromatography}

The aqueous phase is drained into an Erlenmeyer flask containing $4 \mathrm{ml}$ of a solution of $22.5 \mathrm{~g}$ of boric acid in Ioo $\mathrm{ml}$ of $5 \mathrm{~N} \mathrm{NaOH}$. One $\mathrm{ml}$ of dimethyl sulfate is added, the sample is vigorously shaken and kept for 30 min at $37^{\circ}$. Two $\mathrm{ml} 5 \mathrm{~N} \mathrm{NaOH}$ and I $\mathrm{ml}$ dimethyl sulfate are added to repeat the methylation procedure.

After 20 to $30 \mathrm{~min}$, Io $\mathrm{ml}$ of $5 \mathrm{~N} \mathrm{NaOH}$ and $2.5 \mathrm{ml}$ of $\mathrm{H}_{2} \mathrm{O}_{2}(30 \%)$ are added. The methylation mixture is then extracted with $25 \mathrm{ml}$ of benzene and the benzene extract is washed twice with $5 \mathrm{ml}$ of distilled water and subjected to column chromatography according to Brown ${ }^{12}$. The estriol-3-methyl ether $\left(\mathrm{E}_{\mathbf{3}}-3 \mathrm{Me}\right)$ fraction is eluted with $20 \mathrm{ml}$ of benzene containing $6 \%$ ethanol $(\mathrm{v}: \mathrm{v})$ into a small round bottom flask to be evaporated on a rotating evaporator.

\section{Measurement}

The residue of the $\mathrm{E}_{3}-3 \mathrm{Me}$ fraction is dissolved in $5 \mathrm{ml}$ of methanol. A 2-ml aliquot serves to measure the ${ }^{3} \mathrm{H}$-labelled material recovered in the $\mathrm{E}_{\mathbf{3}}-3 \mathrm{Me}$ fraction by liquid scintillation counting. Two I-ml aliquots are subjected to the Kober reaction which is carried out according to the modification of Nocke ${ }^{11}$. The optical density (D) of the developed colors is read at $480,5 \mathrm{I} 8$ and $556 \mathrm{~m} \mu$ and the corrected optical density $\left(D_{\text {eorr }}\right)$ is calculated by applying Allen's formula: $D_{\text {corr }}=2 D_{518}-\left(D_{480}+\right.$ $\left.\mathrm{D}_{556}\right)$.

The amount of estriol excreted per $24 \mathrm{~h}$ is determined by the following formula, where $A$ represents the number counts/min of ${ }^{3} \mathrm{H}$ added, $R$ the number of counts $/ \mathrm{min}$ ${ }^{3} \mathrm{H}$ recovered, $S$ the sum of $\mathrm{D}_{\text {corr }}$ of the two I-ml aliquots analyzed, $T V$ the total 24-h urine volume, $A L$ the aliquot assayed and $F$ the factor to convert $\mathrm{D}_{\text {corr }}$ into $\mu \mathrm{g}$ of $\mathrm{E}_{3}$ :

$$
\mathrm{E}_{3}=\frac{A \times S \times T V \times F}{R \times A L}
$$

The factor $F$ is calculated from calibration curves which are prepared with each batch of hydroquinone-sulphuric acid reagent ${ }^{11}$.

\section{RESULTS}

\section{Precision}

The precision of the method was estimated by carrying out repeated estriol assays on $15-\mathrm{ml}$ aliquots from a pool of pregnancy urine and calculating the standard deviation (S.D.) of the results from their mean. Eighteen determinations were performed. The mean value and its S.D. were $270 \pm 12.3 \mu \mathrm{g}$, indicating a S.D. of $\pm 4.6 \%$. 
From roo routinely performed estriol assays it was calculated that an additional error of $\pm 2.9 \%$ (S.D.) would occur if estriol would be quantitated on the basis of a single colorimetric determination instead of performing Kober reaction and colorimetry on 2 aliquots per assay, as proposed in this paper.

\section{Specificity}

Aliquots of $\mathrm{E}_{3}-3 \mathrm{Me}$ fractions were pooled from a large number of routinely performed estriol assays. Aliquots of this pool were subjected to the Kober reaction. The spectrum of their Kober chromogens closely resembled that of authentic $\mathrm{E}_{3}-3 \mathrm{Me}$.

Aliquots of the $\mathrm{E}_{3}-3 \mathrm{Me}$ pool were subjected to thin-layer chromatography using systems A (ethyl acetate 45-cyclohexane 45-ethanol Io) and L (chloroform 90ethanol Io) of Lisboa ${ }^{13}$. After the plates had been subjected to the anisaldehydesulphuric acid color reaction performed according to Iisboa and Diczfalusy ${ }^{14}$, only one spot was detected exhibiting $R_{F}$ values identical to those of authentic $\mathrm{E}_{3}-3 \mathrm{Me}$ (0.36 and 0.14 in systems $A$ and $L$, respectively).

Another aliquot of the $\mathrm{E}_{3}-3 \mathrm{Me}$ pool was subjected to a 24 -transfer $\mathrm{CCD}$ in carbon tetrachloride 500-methanol 200 -water 300 . Some $96 \%$ of the ${ }^{3} \mathrm{H}$-labelled as well as the Kober chromogenic material was distributed in a single binomial curve $(K=0.6)$ and a constant S.A. was obtained.

\section{Accuracy}

The accuracy of the method was determined by measuring the recovery of authentic $\mathrm{E}_{3}-\mathrm{I} 6 \mathrm{Gl}$ added to the urine of a male subject known to excrete less than o.I $\mu \mathrm{g}$ of estriol per Io $\mathrm{ml}$ of urine. One $\mathrm{mg}$ of estriol was added in the form of $\mathrm{E}_{3^{-}}$ I6Gl to Ioo $\mathrm{ml}$ of urine and eight $\mathrm{I} 0-\mathrm{ml}$ aliquots were analyzed. The mean recovery and its S.D. were $\mathbf{I} 00.5 \pm 2.2 \mu \mathrm{g}$, indicating a virtually complete recovery.

From 300 estriol assays which were routinely performed by 2 operators it was calculated that the recovery of ${ }^{3} \mathrm{H}$-labelled material amounted to $59.6 \%$. The S.D. was \pm II. 5 , about \pm I $9 \%$ of the mean recovery.

\section{Convenience}

Six samples may be completed by one operator within a working day. An accurate result will be obtained within less than $8 \mathrm{~h}$ following the completion of a 24 -h urine collection. Relatively inexperienced operators will produce reliable determinations. Only 3 out of about 600 assays had to be repeated because less than $2 \%$ of the $\left[{ }^{3} \mathrm{H}\right] \mathrm{E}_{3}-\mathrm{I} 6 \mathrm{Gl}$ was found to be hydrolyzed and no Kober chromogenic material could be measured.

\section{DISCUSSION}

Out of the large number of methods to determine urinary estriol in pregnancy just a few assays utilize labelled estriol to correct for methodological loss. Only the method described by Jaffe and Levitz ${ }^{15}$ employs $\left[{ }^{3} \mathrm{H}\right] \mathrm{E}_{3}-\mathrm{I} 6 \mathrm{Gl}$ to account for losses due to incomplete hydrolysis. Approximately $95 \%$ of all the estriol excreted in pregnancy urine was found to be present in the form of glucosiduronates, mainly as $\mathrm{E}_{3}-\mathrm{I} 6 \mathrm{Gl} 1^{7}$. Labelled $\mathrm{E}_{3}-\mathrm{I} 6 \mathrm{Gl}$ therefore appears to be the most suitable recovery standard rendering this method close to $100 \%$ accurate. Incomplete hydrolysis has been 
encountered in routinely performed estriol assays. Without the addition of labelled $\mathrm{E}_{3}$-I6Gl, falsely and even alarmingly low estriol values would have been reported.

The method presented is reasonably precise. Its precision and accuracy are not only due to the utilization of labelled $\mathrm{E}_{3}-\mathrm{I} 6 \mathrm{Gl}$, but are also achieved by the reliability of the Kober reaction when performed following methylation and chromatography, two essential steps of Brown's original procedure ${ }^{12}$. The method of Jaffe and Levitz ${ }^{15}$ does not include methylation and chromatography and is therefore shorter and more convenient. The latter method, however, employs Ittrich's extraction of the Kober chromogens ${ }^{16}$ and fluorimetry to compensate for its shorter purification procedure. Although the procedure of Jaffe and Levitz appears to be reliable, there still remains the possibility of occasional quenching of fluorescence which would result into falsely low estriol measurements.

A somewhat lower precision is obtained if only one aliquot per assay is measured colorimetrically. It remains a matter of opinion whether or not the additional error of $\pm 2.9 \%$ (S.D., $n=100$ ) warrants the efforts of performing routinely Kober reaction and colorimctry in duplicates. It appears advisable, however, to measurc the Kober chromogens in duplicates whenever small amounts of $\mathrm{E}_{3}-3 \mathrm{Me}$ are likely to be encountered as in cases of suspected intra-uterine fetal death.

Adequate specificity has been achieved. When additional steps of Brown's original procedure ${ }^{12}$ were omitted in this method, it became less specific as evidenced by thin-layer chromatography. At its present length the proposed method remains reasonably convenient. One operator may perform 6 assays within a normal working day and no more than average skills are required.

The normal range of estriol excretion is large and may vary significantly in the same subject from day to day. As Klopper ${ }^{8}$ indicated "it is essential that this element of physiological variability should not be farther compounded by methodological error if estriol assays are to be of clinical value". Our method, without its recovery control, would measure approximately $60 \%$ of the true estriol excretion with a S.D. $(n=300)$ of $\pm 19 \%$ of the mean recovery. It is obvious how low the true estriol excretion must drop before it becomes significant if measured with one of the many short and uncorrected assays.

The method presented has not yet been employed to measure the urinary excretion of estriol in a large number of uncomplicated pregnancies. Klopper and Billewic $z^{17}$ have measured estriol excretion in normal pregnancies by using the method of Klopper and Wilson ${ }^{18}$, which is comparable to this method except that it does not utilize a labelled internal standard to correct for methodological losses. Our normal values were found to be within the range of those reported by Klopper and Billewicz ${ }^{17}$ if their values are corrected for an average recovery of $80 \%$.

\section{ACKNOWLEDGEMENTS}

The author is indebted to Professor W. Allen, St. Louis, Mo., U.S.A., for a generous gift of authentic estriol-r6-glucosiduronate.

The technical assistance of Mrs. Catalina Acedo is gratefully acknowledged.

The costs of this investigation were defrayed by grant No. 34I II from the Michigan Memorial Phoenix Project. 


\section{REFERENCES}

I E. Diczfalusy and G. Benagiano, in C. Sassens (Ed.), Research on Stevoids, 2 (1966) 27.

2 U. Goebelsmann, N. Wigvist, E. Diczfalusy, M. Levitz, G. P. Condon and J. Dancis, Acta Endocrino.l, 52 (1966) 550.

3 U. Goebelsmann, G. ERiksson, E. Diczfalusy, M. Levitz nnd G. P. Condon, Acta Endocrinol., 53 (I966) 39I.

4 M. Levitz, G. P. Condon, J. Dancis, U. Goebelsmann, G. Eriksson and E. Diczfalusy, $J$. Clin. Endocrinol., 27 (I967) I723.

5 U. Goebelsmann, G. Eriksson, N. Wigvist and E. Diczralusy, Acta Endocrinol, 50 (i965) 273.

6 U. Goebelsmann, I. Cooke, N. Wigvist and E. Diczfalusy, Acta Endocrinol., 52 (1966) 30.

7 U. Goebelsmann, N. Wiqvist and E. Diczfalusy, Acta Endocrinol., 59 (I968) 595.

8 A. Klopper, Obstet. Gynecol. Survey, 23 (1968) 8I3.

9 R. W. Slaunwhite, JR., M. A. Lichtman and A. A. Sandberg, J. Clin. Endocrinol., 24 (1964) 638.

io C.- G. Beling, Acta Endocrinol., Suppl. 79 (1963).

1 I W. Nocke, Biochem. $J, 78$ (I96r) 593.

I 2 J. B. BRown, Biochem. J., 60 (1955) 185.

I 3 B. P. Lisboa, Clin. Chim. Acta, I 3 (1966) I 79 .

I 4 B. P. Lisboa and E. Diczfalusy, Acta Endocrinol., 43 (I963) 545.

I5 S. H. JafFe and M. Levitz, Am. J. Obstet. Gynecol., 98 (I967) 992.

I6 G. ItTrich, $Z$. Physiol. Chem., 312 (1958) I.

I 7 A. Klopper and W. Billewicz, J. Obstet. Gynaecol. Brit. Commonwealth, 70 (1963) I024.

I8 A. Klopper and G. R. Wilson, J. Obstet. Gynaecol. Brit. Commonwealth, 69 (Ig62) 533.

Clin. Chim. Acta, 23 (1969) 469-474 